\title{
Apparent Monosomy of a G Autosome in a Jamaicar离 Infant
}

\author{
MARIGOLD J. THORBURN and BARBARA E. JOHNSON
}

From the Department of Pathology, University of the West Indies, and The Children's Hospital, Kingston, famaica, W.

Monosomy of an autosome is widely thought to be lethal (Patau, 1963). Deficiencies due to deletions of chromosomes 18 and 5 are well documented (de Grouchy, Lamy, Thieffry, Arthuis, and Salmon, 1963; Lejeune, Lafourcade, Berger, Vialatte, Boeswillwald, Seringe, and Turpin, 1963), and reciprocal translocations which can arise in a carrier person and result in unbalanced offspring with duplications/deficiencies are also described (Clarke, Stevenson, Davies, and Williams, I964; Uchida, Wang, Laxdal, Zaleski, and Duncan, r964; Cowie, Kahn, and O'Reilly, 1965). Lejeune, Berger, Réthoré, Archambault, Jérôme, Thieffry, Aicardi, Broyer, Lafourcade, Cruveiller, and Turpin (1964) have also described a case in which they postulate mosaicism involving monosomy of chromosome $2 \mathrm{I}$ with a partial monosomy of $2 \mathrm{I}$.

\section{Case Report}

We here describe a patient whose karyotypes are suggestive of monosomy of an autosome of the G group, though mosaicism cannot be excluded, as only one tissue was examined.

Clinical Data. The only child of a mother aged 18 and a father in the early thirties, was first seen at the Children's Hospital, Kingston, on September 12, 1965 at the age of $I$ year. The main complaints were of failure to thrive, intermittent fevers, and vomiting and diarrhoea of 6 weeks' duration.

She was born at home in a country district of Jamaica after a medically unsupervised full-term pregnancy and normal delivery. The birthweight was not known. There was no family history of any malformation. Since birth it had been noted that the thumbs were always held drawn across the palms. Apart from this, the mother claimed that the child had developed normally until the onset of this illness. However, the infant had never attempted to crawl or stand, but had been sitting with support since the age of 6 months. On examination at the age of I year, she weighed $9 \mathrm{lb}$. I I oz. (4393 g.) and was marasmic and dehydrated with oedema of the

Received January 24, 1966. lower limbs. The head circumference was 17.5 inंw $(44 \mathrm{~cm}$.). The external abnormalities noted were eyes with an antimongoloid slant, large low-set floppy earsiv a small receding chin, a high-arched palate, and promino ence of the occiput (Fig. I). The thumbs were hel\$ flexed, but the fingers, though slightly flexed, did not overlap. The palmar creases appeared abnormal wittg two transverse creases, the distal one being morg transverse than normal. There was prominent anterio bulging of the thoracic cage more marked on the righto The tone in the lower limbs was slightly increased an they were held partially flexed at the hips and knees There was also difficulty in abducting the legs at tho hips. The external genitalia were normal, and no abnormalities were detected in the cardiovascular systemp the eyes, or the ears. The clinical diagnosis was marasmic malnutrition superimposed on a possible chromosomal abnormality, which superficially resembled I 8 trisomy.

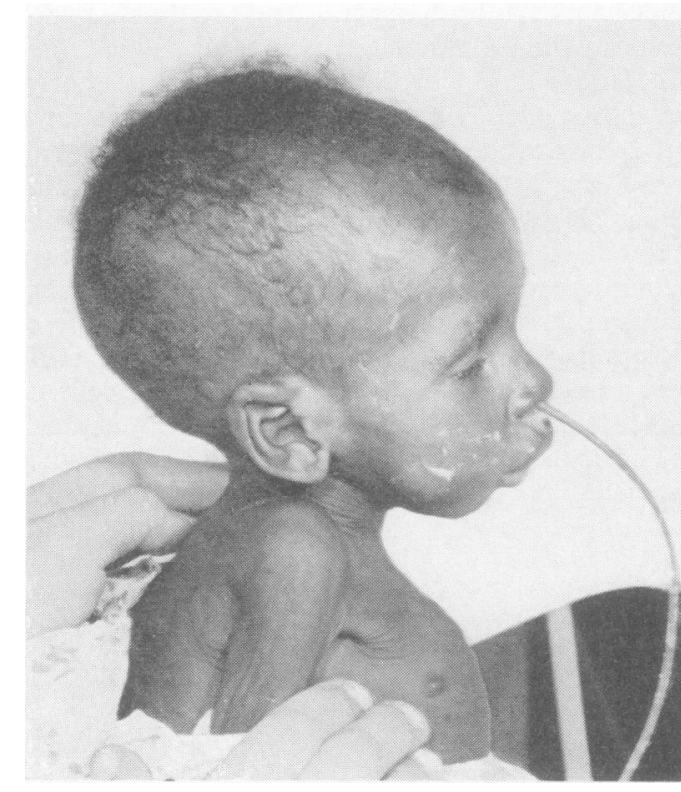

FIG. I. Clinical features of patient at $I$ year. 


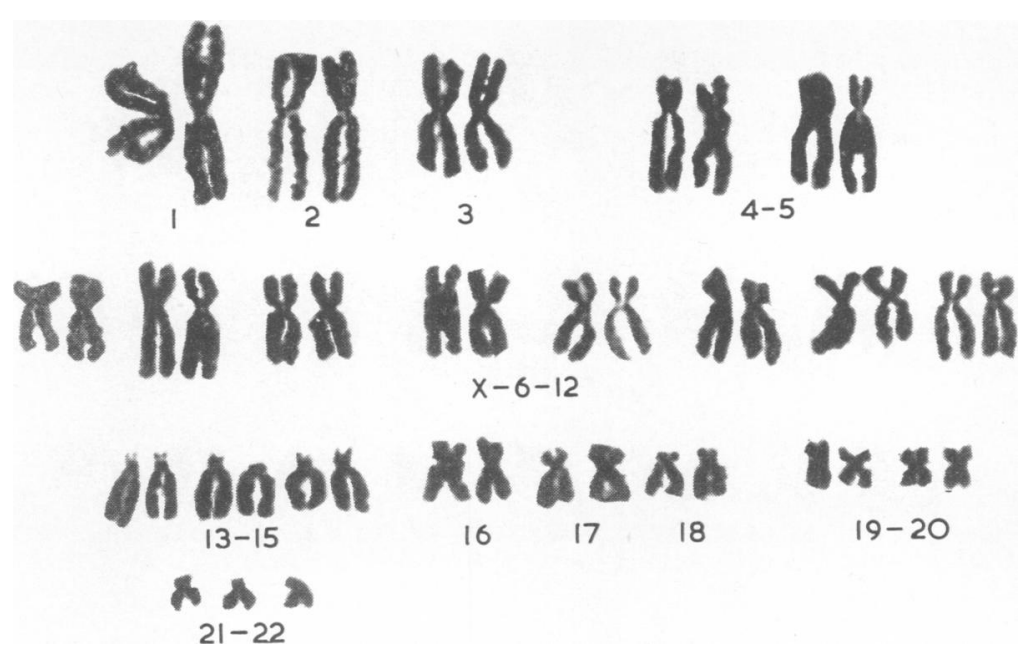

Fig. 2. Karyotype of patient.

Laboratory investigations included the following: $\mathrm{Hb} 9.0 \mathrm{~g}$.; total proteins $4.4 \mathrm{~g}$., albumin $\mathrm{I} \cdot 8$, globulin 2.6. VDRL, stool cultures, and tuberculin test were negative. Radiographs of skull and skeletal survey were reported as normal. Unfortunately blood group studies were not performed, as the significance of the diagnosis was not perceived until too late.

The infant did not respond to the usual therapy for malnutrition and she died of bronchopneumonia II days after admission.

At necropsy (Dr. C. F. Hutchinson) no further congenital abnormalities were discovered, except that the right kidney appeared slightly abnormal in shape. The lungs showed severe bronchopneumonia, and the liver revealed fatty change seen in malnutrition. Histological examination confirmed the two latter pathological findings and revealed no further abnormalities.

Cytogenetic Examination. Peripheral blood was taken from both the patient and her mother. Short-term lymphocyte cultures were performed by the method of Arakaki and Sparkes (1963). In the infant, the mitotic rate was poor but 26 metaphases of good quality were counted and analysed. Karyograms were made from 5 cells. Three cells containing only 44 chromosomes were presumed broken. The remaining 23 cells all contained only 45 chromosomes with a chromosome missing from the group 2I-2I (Fig. 2). In some of the cells, one chromosome 16 appeared larger than its homologue. This finding also appeared in some of the mother's cells. Otherwise it was possible to pair well the remaining chromosomes, and in no cell was a fragment or any morphological indication of a translocation seen.

The mother, in an analysis of 30 cells, showed 46 chromosomes in all cells, and apart from the finding of chromosome I6, no other abnormalities were detected
(Fig. 3). Unfortunately the patient's father could not be traced.

\section{Discussion}

It was thought that by examining the parents of the patient, a balanced translocation would be uncovered which would satisfactorily explain what appears, on the face of it, to be monosomy of chromsome 21 or 22 . In the absence of the father, one can only conjecture on the interpretation of the findings. We can make three possible suggestions.

(i) An unbalanced translocation of part of the missing $G$ autosome resulting in an undetectable increase in size of another chromosome. This could have arisen in the early divisions of the zygote, in one of the parents as a single event in one of the gonia, or as an event that resulted in gonosomic mosaicism or the formation of a parent carrier of a translocation for which the parent was balanced. It was felt that the increase in size of the No. I6 chromosome seen in some of the cells of the infant and her mother probably represented the normal range of variation for chromosome 16 . If the mother had a balanced translocation involving a G chromosome and chromosome 16 , the distribution of the remainder of the chromosomes in the karyotype would have been altered or one of the $\mathrm{G}$ chromosomes would have been reduced in size.

(ii) Mosaicism, undetected in our patient because of examination of an insufficient number of cells and only one tissue. This could be of the type described by Lejeune et al. (1964) in which a monosomy $G$ line existed with a line containing a small fragment which was concluded by the 


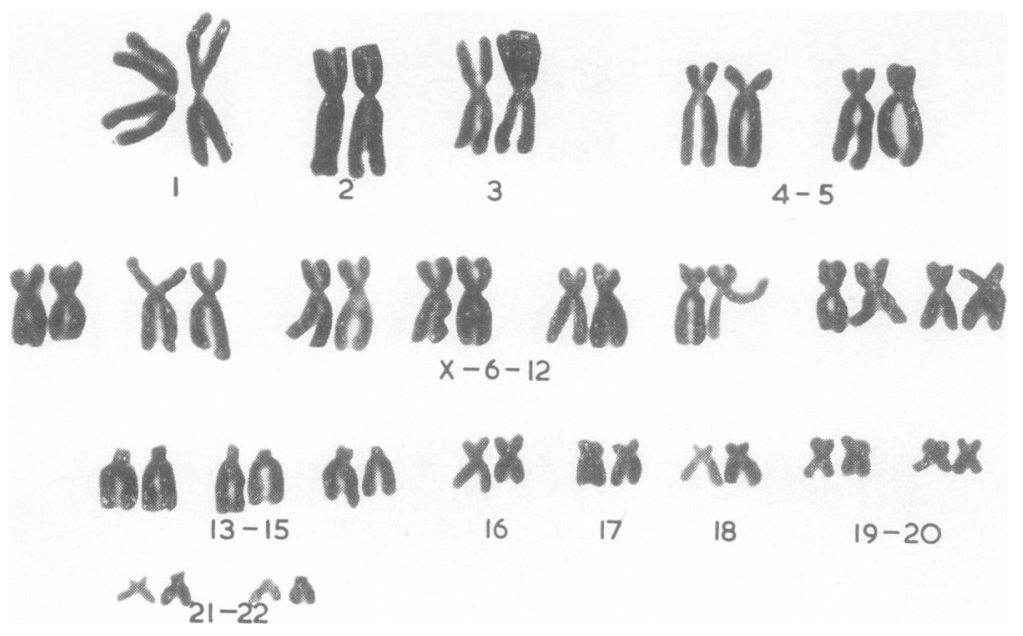

Fig. 3. Karyotype of mother.

authors to be either a ring chromosome or a small part of chromosome 2I. They feilt that the high proportion of cells without the fragment was due to selection through mitotic instability. Our patient resembles clinically the description given by Lejeune et al., though no photographs were shown. They also compared their patient's anomalies with the stigmata of trisomy $2 \mathrm{I}$ and commented that the contrast in the clinical features recalled those of the haplo IV and triplo IV states seen in Drosophila.

(iii) The final possibility is complete monosomy for a G autosome (which has not, to the authors' knowledge, yet been reported in either living individuals or spontaneous abortions). We are, therefore, reluctant to conclude that the findings in this patient indicate complete monosomy, but feel that there is almost certainly loss of some material from chromosomes $2 \mathrm{I}$ and 22 likely to result in the physical abnormalities described above. Of the suggestions we have made, alternative (ii) appears to be the most likely explanation.

\section{Summary}

A child with an abnormal phenotype, who died of malnutrition and bronchopneumonia, is reported. Examination of the chromosomes of the peripheral blood showed loss of some material from chromosome 21 or 22 , and suggested a possible monosomy of a $G$ autosome. Unbalanced and reciprocal translocation, as well as mosaicism, were also considered.

We are grateful to Dr. Leila Wynter, for permission to publish this case and to Professor Paul E. Polani for $\mathscr{O}$ his helpful criticism. The cytogenetic work was sup-? ported by grants from the Wellcome Trust and the Standing Advisory Committee for Medical Research in the British Caribbean. Pure Heparin B.P. was donated by Boots Pure Drug Company, Nottingham.

\section{REFBRENCES}

Arakaki, D. T., and Sparkes, R. S. (1963). Microtechnique for culturing leukocytes from whole blood. Cytogenetics, 2, 57.

Clarke, G., Stevenson, A. C., Davies, P., and Williams, C. E. (1964). A family apparently showing transmission of a translocation between chromosome 3 and one in the ' $\mathrm{X}-6-12$ ' or ' $\mathrm{C}$ ' group. 7. med. Genet., 1, 27.

Cowie, V., Kahn, J., and O'Reilly, J. N. (1965). Congenital abnormalities in a child with an apparently balanced karyotype $\bar{\sigma}$ carrying a reciprocal D/F translocation. Lance; 1 , 1043.

de Grouchy, J., Lamy, M., Thieffry, S., Arthuis, M., and Salmon, C. (1963). Dysmorphie complexe avec oligophrénie; délétion des Oุ bras courts d'un chromosome 17-18. C.R. Acad. Sci. (Paris), 256, I028.

Lejeune, J., Berger, R., Réthoré, M. O., Archambault, L., Jérôme, 음 H., Thieffry, S., Aicardi, J., Broyer, M., Lafourcade, J., Cruveiller, J., and Turpin, R. (1964). Monosomie partielle pour un petit acrocentrique. ibid., 259, 4187.

-, Lafourcade, J., Berger, R., Vialatte, J., Boeswillwald, M., Seringe, P., and Turpin, R. (1963). Trois cas de délétion partielle du bras court d'un chromosome 5. ibid., 257, 3098.

Patau, K. (1963). The origin of chromosomal abnormalities. Path. N et Biol., $11,1163$.

Uchida, I. A., Wang, H. C., Laxdal, O. E., Zaleski, W. A., and $\mathcal{W}$ Duncan, B. P. (1964). Partial trisomy-deficiency syndrome $O$ resulting from a reciprocal translocation in a large kindred. Cytogenetics, 3, 81. 